\title{
A NOVEL FLUORESCENCE SENSOR FOR THE DETECTION OF CHLORIDE ION IN ARTIFICIAL SWEAT AND ENVIRONMENTAL WATER WITH NITROGEN-DOPED GRAPHENE QUANTUM DOTS
}

\author{
Xuemei Fan ${ }^{\mathrm{a}, \mathrm{b}, \mathrm{c}, *,(1)}$, Shumin Wang ${ }^{\mathrm{b}}$, Zhejian Li $^{\mathrm{b}}$, Ping Liu ${ }^{\mathrm{b}}$, Yimeng Wang ${ }^{\mathrm{b}}$, Qiangqiang Sun ${ }^{\mathrm{b}}$, Lingmin Yu and Xinhui Fan ${ }^{\mathrm{a}, \mathrm{b}}$ \\ ${ }^{a}$ School of Materials science and Chemical Engineering, Xi' an Technological University, Xi' an, 710021, China \\ ${ }^{\mathrm{b}}$ College of Chemical Engineering and Modern Materials, Shangluo University, Shangluo, 726000, China \\ ${ }^{\mathrm{c}}$ Research Centre of Graphene Technology and Application, Shangluo University, Shangluo, 72600, China
}

Recebido em 08/04/2021; aceito em 12/07/2021; publicado na web em 03/08/2021

\begin{abstract}
A new fluorescent detection route for chloride ion was designed with Nitrogen-doped graphene quantum dots (N-GQDs), which were prepared by a traditional hydrothermal method with citric acid as carbon source and urea as nitrogen source. The prepared N-GQDs solution was light yellow, and the freeze-dried solid was black. It emitted blue light under ultraviolet light. Meanwhile, The N-GQDs were characterized by TEM, XRD, UV-Vis and fluorescence, the results indicated that the N-GQDs had good dispersibility, photostability and excitation independent emission fluorescence. After addition of $\mathrm{Ag}^{+}$solution, $\mathrm{Ag}^{+}$combined to the surface functional groups of N-GQDs, resulting in an obvious quenching of the fluorescence intensity of N-GQDs. Nevertheless, the fluorescence intensity recovered significantly with the addition of $\mathrm{Cl}^{-}$to the $\mathrm{N}-\mathrm{GQDs} / \mathrm{Ag}^{+}$system, this was because of $\mathrm{AgCl}$ was formed due to the "soft hard acid base principle". The change of fluorescence intensity had a linear response to the chloride ion concentration in the range of 8.5-300 $\mu \mathrm{mol} \mathrm{L}^{-1}$, with a detection limit (LOD) of $0.1 \mu \mathrm{mol} \mathrm{L} \mathrm{L}^{-1}$. To authenticate the application, the proposed method has been successfully used for quantitative analysis of chloride ion in real samples, including artificial sweat and environmental water.
\end{abstract}

Keywords: nitrogen-doped graphene quantum dots; chloride ion; fluorescence.

\section{INTRODUCTION}

Chloride ion $\left(\mathrm{Cl}^{-}\right)$is one of the most common anion, which is indispensable for disinfection in environmental water and is extensively used in many production processes. ${ }^{1}$ The excess $\mathrm{Cl}^{-}$would easily accelerate corrosion reaction of industrial equipment, inhibit crop growth and lead to soil acidification and salinization. ${ }^{2}$ In addition, the salt content of canned foods exceeding the recommended salt limit is harmful to human health. ${ }^{3}$ In particular, the monitoring of $\mathrm{Cl}^{-}$in serum, urine and sweat is essential for the diagnosis of many diseases, including fatal Cystic Fibrosis. ${ }^{4}$ Therefore, a fast and accurate method for $\mathrm{Cl}^{-}$detection is necessary.

Several techniques including titration, ${ }^{5}$ colorimetry, ${ }^{6,7}$ mass spectrometry, ${ }^{8}$ ion chromatography ${ }^{9-11}$ and electrochemistry, ${ }^{12-15}$ have been applied for the detection of $\mathrm{Cl}^{-}$. Fluorescence is a powerful technology due to its salient advantage such as simple, reliable, economic and high sensitive. In recent years, a number of fluorescent materials such as $\mathrm{Ag}^{+}$-benzimidazole complexes, ${ }^{16}$ lucigenin-doped silica nanoparticles, ${ }^{17} \mathrm{Ag}$-modified porous $\mathrm{g}-\mathrm{C}_{3} \mathrm{~N}_{4}$ nanosheets ${ }^{18}$ and $\mathrm{BeQ} 1$ and $\mathrm{BeQ} 2^{19}$ have been reported for the detection of $\mathrm{Cl}^{-}$.

Graphene quantum dots (GQDs), a late-model zero-dimensional (0D) luminescent nanomaterials of the graphene family with a size of less than $10 \mathrm{~nm},{ }^{20}$ have been widely used for their unique characteristics of good electronics, good water-solubility and excellent biocompatibility, as well as non-toxicity and strong photoluminescence. ${ }^{21}$ As a new type of quantum dots, GQDs have superior optical and electrical properties over the traditional semiconductor quantum dots owing to their quantum confinement and edge effects. ${ }^{22}$ Nevertheless, the application of GQDs in fluorescent probes has been limited for its non-specificity and low quantum yield. ${ }^{23}$ So, some heteroatom such as $N, S, B$ and $P$ have been doped into GQDs to improve the optical properties of GQDs. ${ }^{24-27}$

In this study, we reported a new label-free fluorescent sensor for

*e-mail: fanxuemei527@ 163.com fast detection of $\mathrm{Cl}^{-}$based on N-GQDs. As illustrated in Scheme 1A, N-GQDs were prepared by a traditional hydrothermal method with citric acid as carbon source and urea as nitrogen source. $\mathrm{Ag}^{+}$had a good affinity for oxygen groups and amino groups on the surface of $\mathrm{N}-G Q D s$, forming N-GQDs/Ag+ ${ }^{+}$complexes, which resulted in an obvious quenching of the fluorescence signal of $\mathrm{N}-\mathrm{GQDs}$. When $\mathrm{Cl}^{-}$was added to the N-GQDs/ $/ \mathrm{Ag}^{+}$system, the fluorescence signal recovered which was due to $\mathrm{AgCl}$ were formed for the strong interaction between $\mathrm{Ag}^{+}$and $\mathrm{Cl}^{-}$(Scheme 1B). The increase value of fluorescence signal was proportional to the concentration of $\mathrm{Cl}^{-}$. Therefore, a fluorescent sensor for detection of $\mathrm{Cl}^{-}$was established. This label-free optical sensor was simple and applied in accurate detection of $\mathrm{Cl}^{-}$in artificial sweat and environmental water successfully.

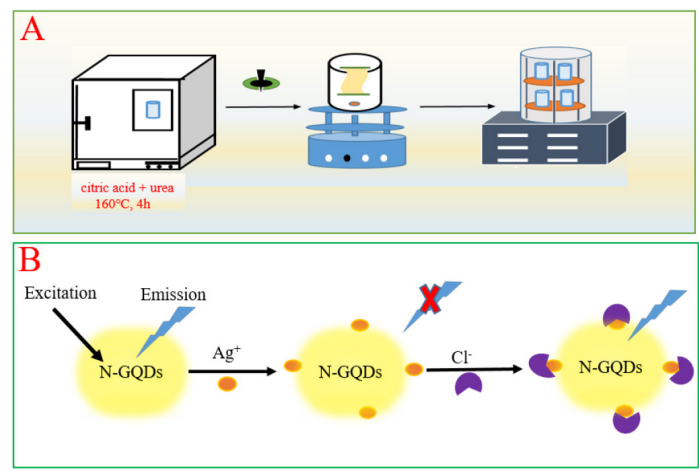

Scheme 1. Schematic illustration showing the preparation process of $\mathrm{N}-G Q D s(A)$, the principle of $\mathrm{Cl}$ assay based on $\mathrm{N}-G Q D s(B)$

\section{EXPERIMENTAL}

\section{Materials and instrumentation}

Citric acid (CA) and urea were obtained from Aladdin Reagent Company. Silver nitrate $\left(\mathrm{AgNO}_{3}\right)$, dihydrate sodium phosphate 
monobasic dehydrate $\left(\mathrm{NaH}_{2} \mathrm{PO}_{4} \cdot 2 \mathrm{H}_{2} \mathrm{O}\right)$ and sodium phosphate dibasic dodecahydrate $\left(\mathrm{Na}_{2} \mathrm{HPO}_{4} \cdot 12 \mathrm{H}_{2} \mathrm{O}\right)$ were purchased from Sinopharm Chemical Reagent Co., Ltd (Shanghai, China). All the reagents are analytical grade and all the working solutions were prepared with ultrapure water $\left(>18.2 \mathrm{M} \Omega \mathrm{cm}^{-1}\right)$ supplied by a Milli-Q Lab system.

LC-10N-50A vacuum freeze dryer was used to freeze-dry the prepared N-GQDs solution (Shanghai lichen Bangxi Instrument Technology Co., Ltd). The morphology and size of the N-GQDs were obtained by the JEM-2100 transmission electron microscopy (JEOL, Japan). X-ray diffraction (XRD) was conducted by PANalytical Xpert Pro (Almelo, Netherlands) in the $2 \theta$ range of $10-80^{\circ}$ with a step size $0.01^{\circ}$ using $\mathrm{Cu} \mathrm{K \alpha}(\lambda=0.154 \mathrm{~nm})$ radiation. The Ultraviolet-visible (UV-vis) absorption spectrum was recorded on a UV-vis spectrometer (UV-2450). The fluorescence spectra was performed by a F-4600 spectrofluorometer (Hitachi, Japan).

\section{Synthesis of N-GQDs}

N-GQDs were synthesized using a hydrothermal method following the procedure described by Chen et al. ${ }^{28} 0.21 \mathrm{~g} \mathrm{CA}$ and $0.18 \mathrm{~g}$ urea were dissolved in a beaker with $25 \mathrm{~mL}$ ultrapure water, then heated in a hydrothermal reactor at $160^{\circ} \mathrm{C}$ for $4 \mathrm{~h}$. The prepared product was filtered with a filter membrane of $0.22 \mu \mathrm{m}$ and dialyzed with a dialysis bag (retaining molecular weight of $1000 \mathrm{Da}$ ) for 3 days to remove impurities. The obtained solution was freeze-dried to obtain the solid, and then N-GQDS with an accurate concentration of $0.1 \mathrm{mg} \mathrm{mL}^{-1}$ was prepared.

\section{Measurement procedure for $\mathrm{Cl}^{-}$}

For $\mathrm{Cl}^{-}$detection, $100 \mu \mathrm{L}$ N-GQDs $\left(0.1 \mathrm{mg} \mathrm{mL}^{-1}\right), 100 \mu \mathrm{L} \mathrm{Ag}^{+}$ $\left(1.0 \times 10^{-5} \mathrm{~mol} \mathrm{~L}^{-1}\right)$ and $200 \mu \mathrm{L} \mathrm{PB}$ buffer $\left(0.01 \mathrm{~mol} \mathrm{~L}^{-1}, \mathrm{pH} 7.0\right)$ were mixed for $20 \mathrm{~min}$. Afterwards, $\mathrm{Cl}^{-}$solution of different concentration was added to the mixture and reacted for $25 \mathrm{~min}$. The fluorescence emission spectra were documented at $450 \mathrm{~nm}$ under the excitation at $360 \mathrm{~nm}$ and $\mathrm{Cl}^{-}$was quantitative by the fluorescence enhancement intensity $\Delta \mathrm{F}=F-F_{0}$, where $F_{0}$ and $F$ represented the fluorescence intensities of the N-GQDs in the presence and absence of $\mathrm{Cl}^{-}$, respectively.

\section{RESULTS AND DISCUSSION}

\section{Characterization of NGQDs}

Figure 1A and Figure 1B showed the transmission electron microscopy (TEM) image and size distributions of the N-GQDs, it revealed that the produced N-GQDs were spherical with size distribution ranging from $1.5 \mathrm{~nm}$ to $5.4 \mathrm{~nm}$. The inset of Figure 1A displayed that the synthesized N-GQDs solution was light yellow, and the freeze-dried solid was black. Figure 1C was the XRD pattern of N-GQDs, the result illustrated that there was a single peak near $2 \theta=24^{\circ}$ of $(002)$ crystal plane, which indicated the formation of GQDs structure. ${ }^{29}$ As can be seen from Figure 1D, the UV-Vis absorption spectra of $\mathrm{N}-\mathrm{GQD}$ exhibited a maximum absorption wavelength of $340 \mathrm{~nm}$, this was just the $n-\pi^{*}$ transition of $\mathrm{C}=\mathrm{O}$ and $\mathrm{C}-\mathrm{N}$ functional groups. ${ }^{30}$ The inset of Figure 1D showed that the aqueous solution of N-GQDs glowed bright blue light when illuminated by an ultraviolet lamp. As depicted in Figure 1E, the maximum fluorescence emission peak of N-GQDs was at $450 \mathrm{~nm}$ with the excitation wavelength at $368 \mathrm{~nm}$, which was consistent with the results reported in the previous literature. ${ }^{21}$ Moreover, as shown in Figure 1F, the emission wavelength of N-GQDs almost unchanged when the excitation wavelength changed in the range of $335-360 \mathrm{~nm}$, this excitation independence indicated that the size and surface state of N-GQDs were consistent. ${ }^{31}$

\section{Feasibility for $\mathrm{Cl}^{-}$assay}

The feasibility for $\mathrm{Cl}^{-}$determination using N-GQD as a fluorescence probe was discussed and the results were exhibited in Figure 2. It was shown that the fluorescence signal of N-GQDs at $450 \mathrm{~nm}$ can be quenched by $\mathrm{Ag}^{+}$, and while adding $\mathrm{Cl}^{-}$to the $\mathrm{N}-\mathrm{GQD} / \mathrm{Ag}^{+}$system, the fluorescence signal was restored to about $91.8 \%$ of the original, which demonstrated that our method for $\mathrm{Cl}^{-}$was feasible. The process can be interpreted that $\mathrm{Ag}^{+}$can form $\mathrm{N}-G Q D s / \mathrm{Ag}^{+}$complexes with $\mathrm{N}-\mathrm{GQD}$ resulting a quenching of the fluorescence of N-GQDs. In addition, when the $\mathrm{Cl}^{-}$was present, $\mathrm{AgCl}$ was further generation for the strong interaction between $\mathrm{Ag}^{+}$and $\mathrm{Cl}^{-}$, so a recover of fluorescence signal was acquired.
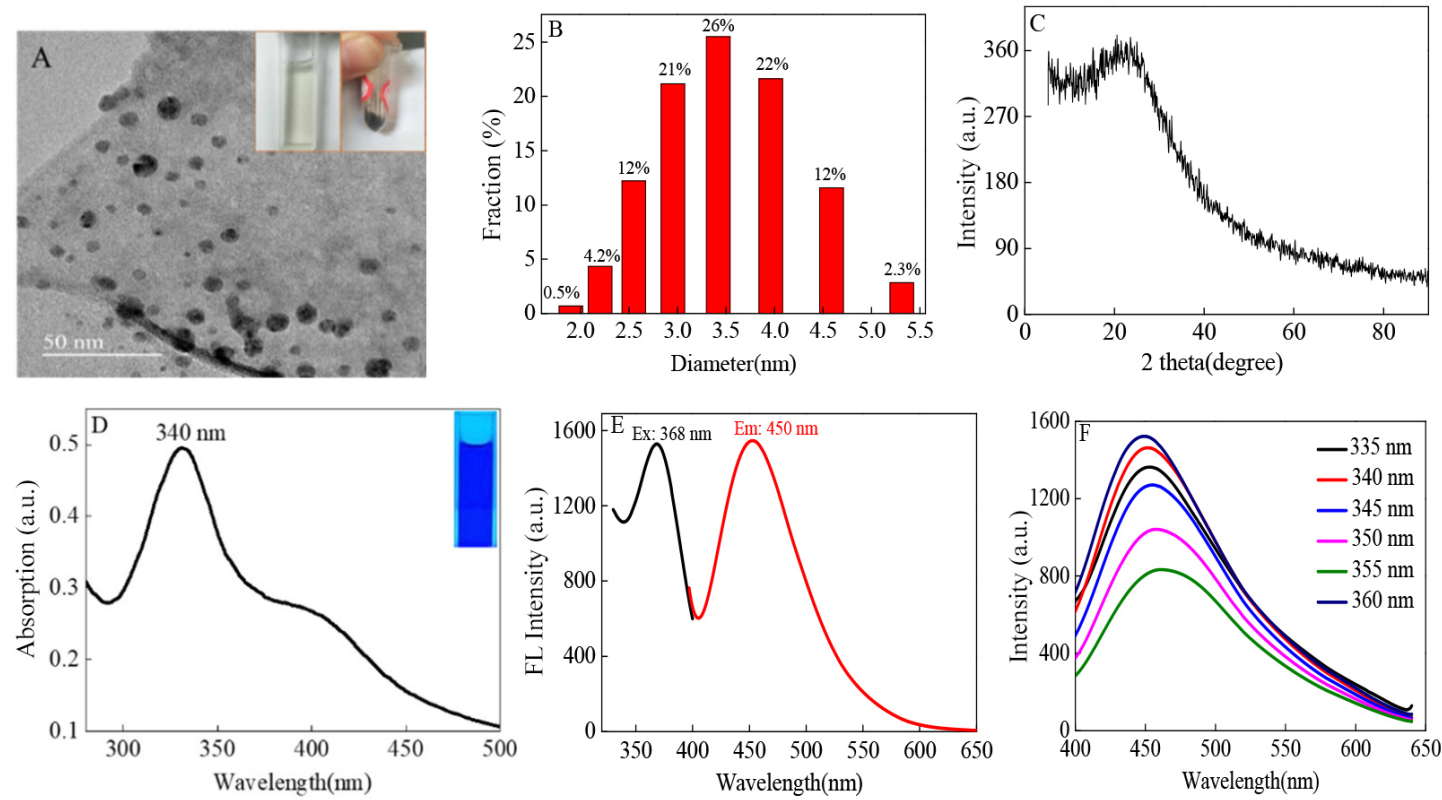

Figure 1. TEM image (A, inset were photos of $N$-GQDs), size distributions (B), XRD pattern (C), UV-Vis spectra (D, inset was photo of $N$-GQDs illuminated by an ultraviolet lamp) and fluorescence spectra $(E)$ of NGQDs; Fluorescence spectra at different excitation wavelengths (F) 


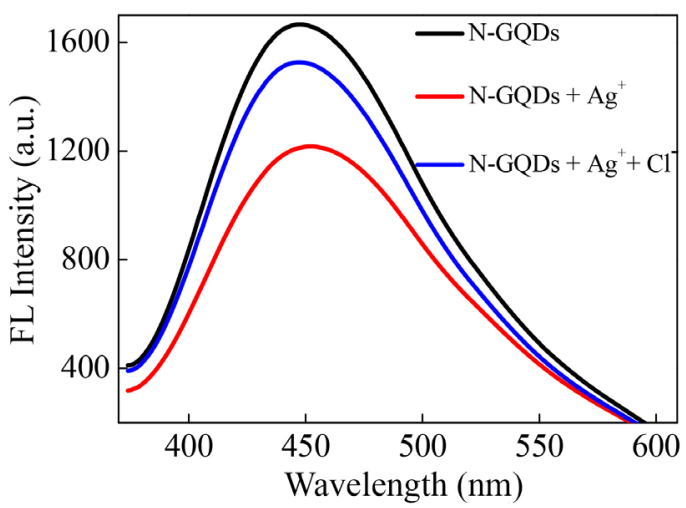

Figure 2. The feasibility for $\mathrm{Cl}$ assay

\section{Fluorescence response strategy for $\mathrm{Cl}^{-}$determination}

The detection performance was elevated by optimizing the experimental conditions, including the concentration and the reaction time of $\mathrm{Ag}^{+}, \mathrm{pH}$ and action time of $\mathrm{Cl}^{-}$, respectively. First of all, the reaction time of $\mathrm{Ag}^{+}$with $\mathrm{N}-\mathrm{GQD}$ s had an effect on the detection of $\mathrm{Cl}^{-}$. Figure 3A displayed that as the reaction time increased, the $\Delta \mathrm{F}$ gradually increased and appeared a platform at $20 \mathrm{~min}$, this indicated that $\mathrm{Cl}^{-}$indeed reacted with $\mathrm{Ag}^{+}$which coming from $\mathrm{N}-\mathrm{GQDs} / \mathrm{Ag}^{+}$ and the fluorescence was recovery. At the same time, it still declared that $\mathrm{Cl}^{-}$can react with all of $\mathrm{Ag}^{+}$successfully at $20 \mathrm{~min}$. Hence, the reaction time for $\mathrm{Ag}^{+}$was set at $20 \mathrm{~min}$. In addition, the influence of $\mathrm{Ag}^{+}$concentration was investigated specifically. It was easy to think that as the increases of the amount of $\mathrm{Ag}^{+}$content, more N-GQDs/ $\mathrm{Ag}^{+}$will be formed, when adding $\mathrm{Cl}^{-}$, more fluorescence signal will be recovery. Figure $3 \mathrm{~B}$ just confirmed this conclusion $(\Delta \mathrm{F}$ increased as the amount of $\mathrm{Ag}^{+}$), it also indicated $\Delta \mathrm{F}$ reached maximum at 1.0 $\times 10^{-5} \mathrm{~mol} \mathrm{~L}^{-1}$. Therefore, $1.0 \times 10^{-5} \mathrm{~mol} \mathrm{~L}^{-1}$ of $\mathrm{Ag}^{+}$was selected. The react time of the fluorescence sensor with $\mathrm{Cl}^{-}$was researched

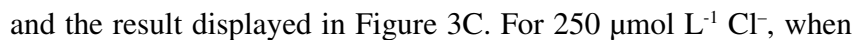
the react time increased from 5 to $30 \mathrm{~min}$, fluorescence intensity
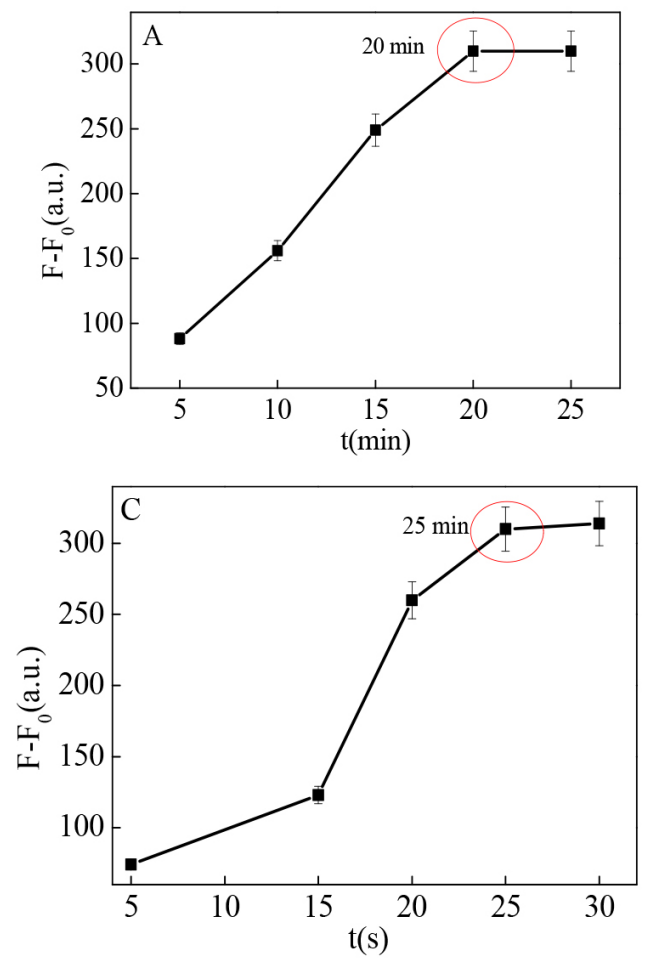

became stable after $25 \mathrm{~min}$, which meant that 25 min can achieve equilibrium. So, the action time of the sensor with $\mathrm{Cl}^{-}$was set at 25 min. As illustrated in Figure 3D, with increasing the $\mathrm{pH}$ in the range of 5.8 to $7.8, \Delta \mathrm{F}$ gradually increased and reached maximum at $\mathrm{pH}$ of 7.0. This was because the amino groups on the surfaces of the $\mathrm{N}-\mathrm{GQD}$ s were protonated at lower $\mathrm{pH}$ and the coordination degree of $\mathrm{Ag}^{+}$with amino groups was responsively reduced, thereby $\mathrm{Cl}^{-}$can only take a small amount of $\mathrm{Ag}^{+}$in $\mathrm{Ag}^{+} / \mathrm{N}-\mathrm{GQD}$, less fluorescence was recovery. Whereas, when the $\mathrm{pH}$ became higher than 7.0, $\mathrm{Ag}^{+}$ may hydrolyze and combine with $\mathrm{OH}^{-}$to form $\mathrm{AgOH}$, which was instability and became to $\operatorname{Ag}_{2} \mathrm{O}$. This lead to the interaction between $\mathrm{Ag}^{+}$and $\mathrm{Cl}^{-}$decreases and less fluorescence was recovery. Therefore, the $\mathrm{pH} 7.0$ was chosen in the future.

\section{Detection of $\mathrm{Cl}^{-}$using N-GQDs as fluorescent probe}

Under the optimal detection conditions, a quantitative detection of $\mathrm{Cl}^{-}$was performed. As shown in Figure 4A, with the concentration of $\mathrm{Cl}^{-}$increase, gradually enhancement of fluorescence intensity was observed. Notably, a good linear relationship was existed between the enhancement of the fluorescence value and the concentration of $\mathrm{Cl}^{-}$ranging from 8.5 to $300 \mu \mathrm{mol} \mathrm{L} \mathrm{L}^{-1}$. The linear regression equation was $F-F_{0}=1.0868 \mathrm{C}+19.4801$ where $\mathrm{C}$ was the concentration of $\mathrm{Cl}^{-}$(Figure 4B). The correlation coefficient was 0.9899. At the same time, the detection limit was calculated to be $0.1 \mu \mathrm{mol} \mathrm{L}^{-1}$ at a signalto-noise ratio of $3(\mathrm{~S} / \mathrm{N}=3)$. We compared our proposed sensor with other methods for $\mathrm{Cl}^{-}$detection. As illustrated in Table 1, though the linear range was not the widest among these sensors, it was wider than those reported by Lima, ${ }^{7}$ Bujes-Garrido, ${ }^{13}$ Bujes-Garrido ${ }^{15}$ and Xiao, ${ }^{17}$ it was obvious that the detection limit was better than most of the reported literatures except Yakoh's, ${ }^{6}$ Lima's $^{7}$ and Wan's work. ${ }^{14}$

In addition, for real application, interference species may effect on the response of $\mathrm{Cl}^{-}$. So, some relatively important cations and anions interfering species such as $\mathrm{Na}^{+}, \mathrm{K}^{+}, \mathrm{Ni}^{2+}, \mathrm{Mg}^{2+}, \mathrm{NO}_{3}^{-}, \mathrm{HCO}_{3}^{-}$and $\mathrm{SCN}^{-}$were carried out to evaluate the selectivity for detection of $\mathrm{Cl}^{-}$, respectively. As can be seen in Figure 5A, after adding different ions
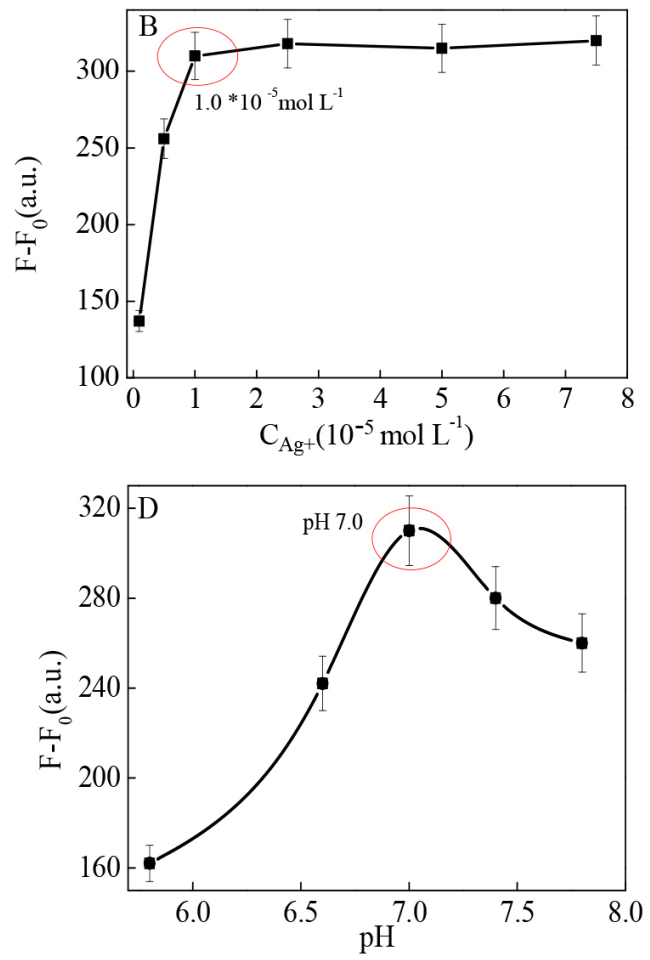

Figure 3. Effect of reaction time $(A)$ and concentration of $\mathrm{Ag}^{+}(B)$, action time of $\mathrm{Cl}^{-}(C)$ and $\mathrm{pH}(D)$ on the fluorescence intensity for the detection of $C l$ 
in N-GQDs/Ag ${ }^{+}$system, it seemed that no significant fluorescence recovery of other ions obtained except for $\mathrm{Cl}^{-}$, demonstrating the binding ability of these ions with $\mathrm{Ag}^{+}$was weaker than that of with $\mathrm{Cl}^{-}$, this can cause unconspicuous fluorescence recover after addition the interfering substance. Furthermore, Figure 5A also depicted that the fluorescence recovery was not obvious when all the above-mentioned common cations and anions co-existed in the NGQDs/ $\mathrm{Ag}^{+}$system. In conclusion, all of the above conclusions can indicate that this method had good selectivity in the detection of $\mathrm{Cl}^{-}$.

Meanwhile, to investigate the stability for detection of $\mathrm{Cl}^{-}$, $80 \mu \mathrm{mol} \mathrm{L}{ }^{-1}$ of $\mathrm{Cl}^{-}$was measured continuously in seven days and the results were shown in Figure 5B, revealing a relative RSD (Relative standard deviation) of $5.09 \%$, this indicated good stability for detection of $\mathrm{Cl}^{-}$in $\mathrm{N}-\mathrm{GQD} / \mathrm{Ag}^{+}$system.

\section{Application in real samples}

In order to assess the application reliability of the method provided, the real water sample obtained from the ShangLuo DanJiang (ShaanXi, China) were quantitatively analyzed (Table 2). The water sample was diluted for double times by $0.01 \mathrm{~mol} \mathrm{~L}^{-1} \mathrm{~PB}(\mathrm{pH} 7.0)$ without any pretreatment. The content of $\mathrm{Cl}^{-}$in real water was not detected, so the standard addition method was carried out to evaluate the reliability of the sensor. Different concentrations of $\mathrm{Cl}^{-}$was added to water sample in the linear range and the fluorescent responses were measured according to the experimental method. The recoveries were between $97.4 \%$ and $103.6 \%$.

Furthermore, the level of $\mathrm{Cl}^{-}$in sweat is a recognized biomarker for the genetic disorder cystic fibrosis. Therefore, the accurate quantitation of $\mathrm{Cl}^{-}$in sweat is an important tool in the diagnosis of this deadly disease. Three artificial sweat samples with different concentrations of $\mathrm{Cl}^{-}\left(20 \mathrm{mmol} \mathrm{L}-1,50 \mathrm{mmol} \mathrm{L}^{-1}\right.$ and $\left.80 \mathrm{mmol} \mathrm{L}^{-1}\right)$ were prepared according to the British Standard (BS EN1811-1999), while diluted for 1000 times and act as the analysis samples. The recovery rate was estimated by standard addition method (Table 3). The recoveries ranged from 96.5 to $104.8 \%$ with the RSD (relative standard deviation) of 2.3 to $3.9 \%$ (Table 3 ). These results indicated that $\mathrm{N}-\mathrm{GQDs} / \mathrm{Ag}^{+}$system can be used for the determination of $\mathrm{Cl}^{-}$in artificial sweat samples, and it had good potential in the detection and diagnosis of cystic fibrosis.
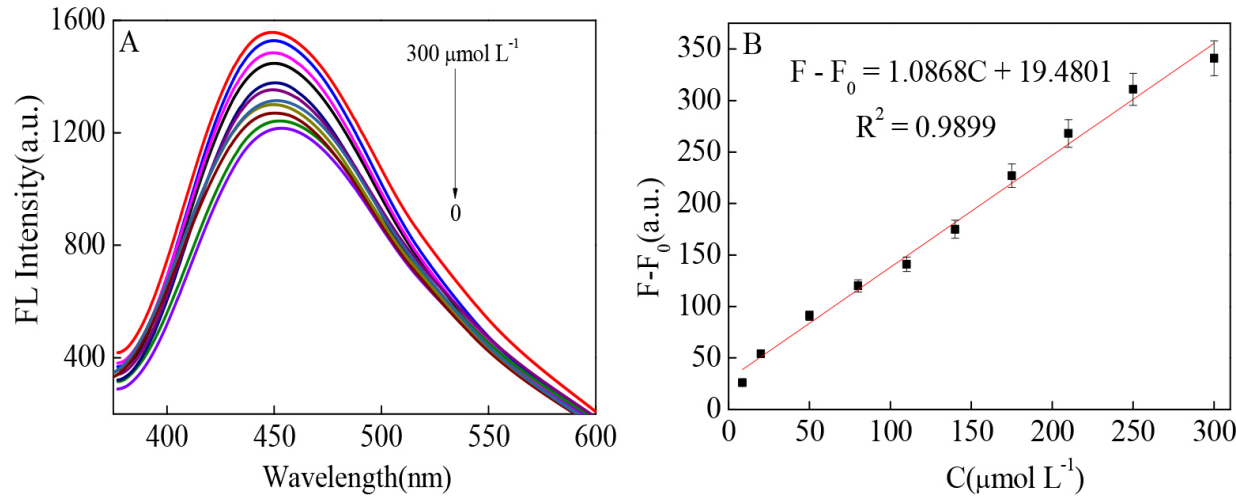

Figure 4. Fluorescence spectra of $\mathrm{Ag}^{+} / \mathrm{N}-\mathrm{GQD}$ under various concentrations of $\mathrm{Cl}^{-}$, from bottom to top: $0,8.5,20,50,80,110,140,175,210,250$ and 300 mol L $L^{-1}$, respectively $(A)$, Calibration curve of $\mathrm{Cl}^{-}(B)$
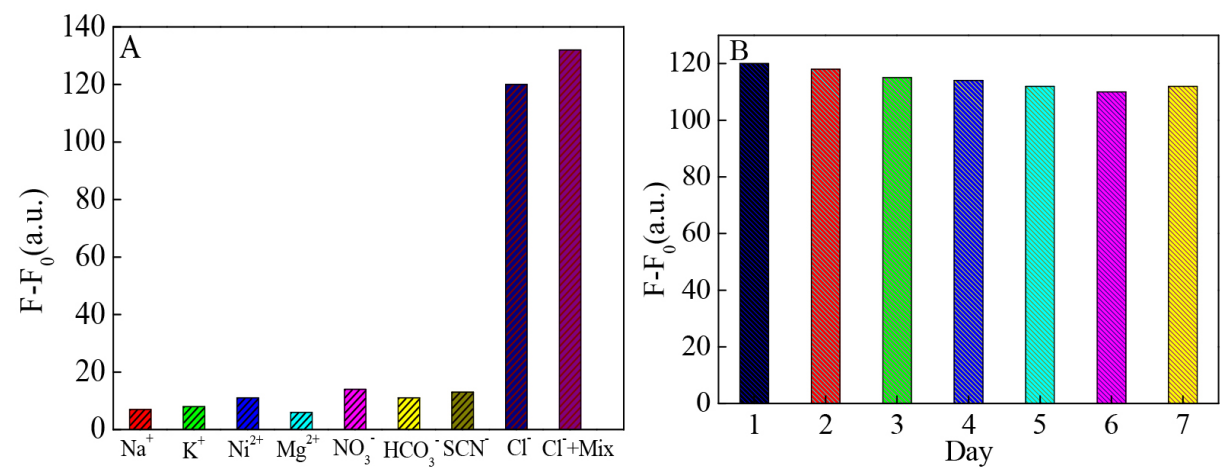

Figure 5. Selectivity (A) and stability (B) for detection of $\mathrm{Cl}^{-}$in $\mathrm{N}-\mathrm{GQDS} / \mathrm{Ag}^{+}$system. $\mathrm{Cl}^{-}: 80 \mu \mathrm{mol} \mathrm{L} \mathrm{L}^{-1}$

Table 1. Compared with other methods for $\mathrm{Cl}^{-}$detection

\begin{tabular}{|c|c|c|c|c|}
\hline Method & Range of linear & Limit detection & Sample & References \\
\hline UV & $28 \mu \mathrm{mol} \mathrm{L}{ }^{-1}-28 \mathrm{mmol} \mathrm{L}^{-1}$ & $3.6 \mu \mathrm{mol} \mathrm{L}-1$ & natural water & [6] \\
\hline UV & $1.4-22.4 \mu \mathrm{mol} \mathrm{L}{ }^{-1}$ & $0.3 \mu \mathrm{mol} \mathrm{L}-1$ & fuel ethanol & [7] \\
\hline Chromatography & $1.4 \mu \mathrm{mol} \mathrm{L}{ }^{-1}-0.42 \mathrm{mmol} \mathrm{L}^{-1}$ & $0.19 \mu \mathrm{mol} \mathrm{L}^{-1}$ & commercial tablet & [11] \\
\hline Electrochemical & $3.0 \mu \mathrm{mol} \mathrm{L}{ }^{-1}-0.1 \mathrm{mmol} \mathrm{L}^{-1}$ & $2.0 \mu \mathrm{mol} \mathrm{L}-1$ & synthetic sweat & [13] \\
\hline Electrochemical & $0.25 \mu \mathrm{mol} \mathrm{L}-1-250 \mathrm{mmol} \mathrm{L}^{-1}$ & $0.16 \mu \mathrm{mol} \mathrm{L}-1$ & sweat and hela cells & [14] \\
\hline Electrochemical & $0.2 \mathrm{mmol} \mathrm{L}^{-1}$ to $0.7 \mathrm{mmol} \mathrm{L}^{-1}$ & $0.1 \mathrm{mmol} \mathrm{L}^{-1}$ & sea water & [15] \\
\hline fluorescence & $0-0.5 \mathrm{mmol} \mathrm{L}^{-1}$ & $19 \mu \mathrm{mol} \mathrm{L}-1$ & artificial sweat & [16] \\
\hline fluorescence & $0.02-0.06 \mathrm{~mol} \mathrm{~L}^{-1}$ & $0.025 \mathrm{~mol} \mathrm{~L}^{-1}$ & environment water & [17] \\
\hline fluorescence & $0.5 \mathrm{mmol} \mathrm{L}^{-1}-0.1 \mathrm{~mol} \mathrm{~L}^{-1}$ & $0.06 \mathrm{mmol} \mathrm{L}^{-1}$ & environment water & [18] \\
\hline This paper & 8.5-300 $\mu \mathrm{mol} \mathrm{L}-1$ & $0.1 \mu \mathrm{mol} \mathrm{L}-1$ & synthetic sweat & - \\
\hline
\end{tabular}


Table 2. Recoveries of $\mathrm{Cl}^{-}$in water sample with the proposed method $(\mathrm{n}=3)$

\begin{tabular}{|c|c|c|c|c|c|}
\hline Sample & Measure & Added $/\left(\mu \mathrm{mol} \mathrm{L} \mathrm{L}^{-1}\right)$ & Found $/\left(\mu \mathrm{mol} \mathrm{L}{ }^{-1}\right)$ & $\mathrm{RSD} / \%$ & Recovery $/ \%$ \\
\hline \multirow[t]{3}{*}{ DanJiang water } & - & 50.0 & 48.7 & 2.7 & 97.4 \\
\hline & & 90.0 & 88.3 & 3.5 & 98.1 \\
\hline & & 130.0 & 134.7 & 3.1 & 103.6 \\
\hline
\end{tabular}

Table 3. Detection and Recoveries of $\mathrm{Cl}^{-}$in artificial sweat samples $(\mathrm{n}=3)$

\begin{tabular}{ccccccc}
\hline Sample & Measured $/\left(\mu \mathrm{mol} \mathrm{L}^{-1}\right)$ & $\mathrm{RSD} / \%$ & Added $\left./(\mu \mathrm{mol} \mathrm{L})^{-1}\right)$ & Found $/\left(\mu \mathrm{mol} \mathrm{L}^{-1}\right)$ & $\mathrm{RSD} / \%$ & $\mathrm{Recovery} / \%$ \\
\hline 1 & 19.6 & 3.1 & 20.0 & 38.9 & 2.3 & 96.5 \\
2 & 51.3 & 2.7 & 50.0 & 100.2 & 2.5 & 97.8 \\
3 & 83.8 & 2.1 & 80.0 & 167.6 & 3.9 & 104.8 \\
\hline
\end{tabular}

\section{CONCLUSIONS}

In conclusion, $\mathrm{N}-\mathrm{GQD}$ s have been synthesized by a hydrothermal method and further characterized by TEM, XRD, UV-Vis and fluorescence. Meanwhile, N-GQDs have been used as a fluorescent probe for $\mathrm{Cl}^{-}$detection. When introducing $\mathrm{Ag}^{+}$into N-GQDs, the fluorescence quenched, while with the addition of $\mathrm{Cl}^{-}$into the $\mathrm{N}-\mathrm{GQDs} / \mathrm{Ag}^{+}$solution, the fluorescence intensity was enhanced. The sensor had a linear response to $\mathrm{Cl}^{-}$in the range of 8.5-300 $\mu \mathrm{mol} \mathrm{L}-1$

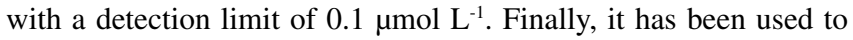
determine of $\mathrm{Cl}^{-}$in artificial sweat and environmental water, the satisfactory results further confirmed its practicability. This work provides a simple and low-cost method for the detection of $\mathrm{Cl}^{-}$, and expands the application of N-GQDs in environmental safety and food safety.

\section{ACKNOWLEDGEMENTS}

This project was supported by the National Natural Science Foundation of China (No. 30970696), the Science and Technology Planning Project of ShaanXi Province (2012KTDZ 02-02) and Science and technology innovation team project of shangluo university (18SCX003).

\section{REFERENCES}

1. Winterton, N.; Green Chem. 2000, 2, 173.

2. Montemor, M. F.; Alves, J. H.; Simoes, A. M.; Fernandes, J. C. S.; Lourenço, Z.; Costa, A. J. S.; Appleton, A. J.; Ferreiraa, M. G. S.; Cem. Concr. Compos. 2006, 28, 233.

3. Ling, B.; Ouyang, S.; Wang, S.; Innov. Food Sci. Emerg. Technol. 2019, $52,158$.

4. Zhang, M.; Wang, C. Q.; Zhang, Z. Y.; Ye, J.; Fang, P. P.; Sens. Actuators, B 2019, 299, 126951.

5. Fakhri, H.; Fishman, K. L.; Ranade, R.; Constr. Build. Mater. 2021, 268, 121148.

6. Yakoh, A.; Rattanarat, P.; Siangproh, W.; Chailapakul, O.; Talanta 2018, $178,134$.

7. Lima, M. J. A.; Reis, B. F.; Talanta 2019, 201, 373.

8. Gajdosechova, Z.; Dutta, M.; López-Linares, F.; Mello, P. A.; Iop G. D.; Flores, E. M. M.; Mester, Z.; Pagliano, E.; Fuel 2021, 285, 119167.

9. Shen, M.; Tu, M. M.; Zhang, W.; Zou, J. H.; Zhang, M.; Cao, Z.; Zou, B. D.; J. Clin. Lab. Anal. 2020, 34, 1.
10. Robaina, N. F.; Feiteira, F. N.; Cassella, A. R.; Cassella, R. J.; J. Chromatogr. A 2016, 1458, 112.

11. Novo, D. L. R.; Pereira, R. M.; Hartwig, C. A.; Santos, C. M. M.; Mesko, M. F.; Talanta 2018, 181, 440.

12. Bin, Q. Y.; Wang, M.; Wang, L. S.; Nanotechnology 2020, 31, 125601.

13. Bujes-Garrido, J.; Izquierdo-Bote, D.; Heras, A.; Colina, A.; ArcosMartínez, M. J.; Anal. Chim. Acta 2018, 1012, 42.

14. Wan, Y. Q.; Hua, Y.; Liu, M.; Li, S.; Yin, M. Y.; Lv, X. X.; Wang, H.; Sens. Actuators, B 2019, 300, 127058.

15. Bujes-Garrido, J.; Arcos-Martínez, M. J.; Sens. Actuators, B 2017, 240, 224.

16. Kim, J.; Lee, S.; Kim, S.; Jung, M.; Lee, H.; Han, M. S.; Dyes Pigm. 2020, 177, 108291.

17. Xiao, W.; Ding, L. Y.; He, J. Y.; Huang, J.; Opt. Mater. 2019, 98 , 109467.

18. Zhang, Z. S.; Gao, Y.; Li, P.; Qu, B. H.; Mu, Z. Y.; Liu, Y.; Qu, Y.; Kong, D. G.; Chang, Q.; Jing, L. Q.; Chin. Chem. Lett. 2020, 31, 2725.

19. Zhang, F. Y.; Ma, C.; Wang, Y. Y.; Liu, W.; Liu, X. Y.; Zhang, H. X.; Spectrochim. Acta A 2018, 205, 428.

20. Tian, P.; Tang, L.; Teng, K. S.; Lau, S. P.; Mater. Today Chem. 2018, 10, 221.

21. Su, D. D.; Wang, M. K.; Liu, Q.; Chen, J. Y.; Su, X. G.; Sens. Actuators, B 2019, 290: 163.

22. Bian, S.; Shen, C.; Qian, Y.; Liu, J.; Xi, F.; Dong, X.; Sens. Actuators, B 2017, 242, 231 .

23. Li, S.; Li, Y.; Cao, J.; Zhu, J.; Fan, L.; Li, X.; Anal Chem. 2014, 86, 10210.

24. Liu, X. T.; Na, W. D.; Liu, Q.; Su, X. G.; Anal. Chim. Acta 2018, 1028, 45 .

25. Nair, R. V.; Thomas, R. T.; Mohamed, A. P.; Pillai, S.; Microchem. J. 2020, 157, 104971.

26. Ge, S. Y.; He, J. B.; Ma, C. X.; Liu, J. Y.; Xi, F. G.; Dong, X. P.; Talanta 2019, 199, 581 .

27. Guo, Z. S.; Wu, H.; Li, M.; Tang, T.; Wen, J. F.; Li, X. Y.; Appl. Surf. Sci. 2020, 526, 146724.

28. Chen, S. F.; Chen, X. Q.; Xia, T. T.; Ma Q.; Biosens. Bioelectron. 2016, $85,903$.

29. Ozyurt, D.; Shafqat, S; Pakkanen, T. T.; Hocking, R. K.; Mouritz, A.; Fox, B.; Carbon 2021, 175, 576.

30. Liu, Y., Liu, C. Y.; Liu, Y.; Appl. Surf. Sci. 2011, 257, 5513.

31. Qu, D.; Zheng, M.; Du, P.; Zhou, Y.; Zhang, L. G.; Li, D.; Tan, H. Q.; Zhao, Z.; Xie, Z. G.; Sun, Z. C.; Nanoscale 2013, 5, 12272. 